\title{
Looking beyond the idyllic representations of the rural: the Konkan Railway controversy and middle-class environmentalism in India
}

\author{
Sreeja Jaiswal ${ }^{1}$ \\ Tata Institute of Social Sciences, India
}

\begin{abstract}
Post-independence India has had its share of controversies around mega-infrastructure projects that have pitted environmental preservation against development concerns. This article studies the environmental controversy around one such megaproject, the Konkan Railway, employing a framework that integrates the environmental values, beliefs and behaviour of individuals and groups with a historical understanding of political economy and ecology (science). Essentialist and over-simplified environmental discourses, without scientific credibility and not based on historical facts, are often influential in policy making, especially when channelled by the middle classes. Better understanding our present concerns and guiding decisions and policies to deal with the problems we currently face, requires unmasking the romanticization of the countryside. We must replace the idyllic version of the past with a nuanced historical understanding of the interaction between nature and culture. This article also locates the controversy over the Konkan Railway within the frames used to study Indian environmentalism. The aim is to improve our understanding of the regional, ideological and cultural pluralities in environmental values, beliefs and behaviour of the middle class in India.
\end{abstract}

Key words: large infrastructure project, South Asia, middle class environmentalism, sustainable development; environmental controversy, romanticization, cultural rationality

\begin{abstract}
Résumé
Après l'indépendance, l'Inde a eu sa part de controverses autour de projets de méga-infrastructures, où la préservation de l'environnement a lutté contre les problèmes de développement. Cet article étudie la controverse environnementale autour d'un tel mégaprojet, le Konkan Railway. Il utilise un cadre qui intègre les valeurs environnementales, les croyances et les comportements des individus et des groupes, et une compréhension historique de l'économie politique et de l'écologie. Les discours environnementaux essentialistes et trop simplifiés, sans crédibilité scientifique et non fondés sur des faits historiques, ont souvent une influence sur l'élaboration des politiques, en particulier lorsqu'ils sont canalisés par les classes moyennes. Mieux comprendre nos préoccupations actuelles et orienter les décisions et les politiques pour faire face aux problèmes auxquels nous sommes actuellement confrontés, il faut démasquer la romantisation de la campagne. Nous devons remplacer la version idyllique du passé par une compréhension historique nuancée de l'interaction entre la nature et la culture. Cet article situe également la controverse sur le chemin de fer Konkan dans les cadres utilisés pour étudier l'environnementalisme indien. L'objectif est d'améliorer notre compréhension des pluralités régionales, idéologiques et culturelles dans les valeurs environnementales, les croyances et le comportement de la classe moyenne en Inde.
\end{abstract}

Mots clés: grands projets d'infrastructure, Asie du Sud, écologisme de classe moyenne, développement durable; controverse environnementale, romantisme, rationalité culturelle

\footnotetext{
${ }^{1}$ Sreeja Jaiswal, PhD candidate, School of Development Studies, Tata Institute of Social Sciences, VN Purav Marg, Mumbai, India. Email: sreeja.jaiswal "at" gmail.com. I would like to thank the Centre for Education and Documentation (CED) for giving me access to their archives. A preliminary version of this paper was presented at the conference titled Knowing nature: the changing foundations of environmental knowledge at Renmin University of China, Beijing on 2527 May 2016. The paper greatly benefited from the detailed feedback and comments from co-participants and attendees of the conference. Thank you to T. Jayaraman for fruitful discussion, two anonymous reviewers, and Simon Batterbury. This research was partly funded by the International Initiative for Impact Evaluation (3ie) under Grant DPW1/1050.
} 


\section{Resumen}

Posterior a su independencia, India ha atravesado por una serie de controversias en proyectos de mega infraestructuras, lo que ha provocado que la conservación ambiental y las preocupaciones de desarrollo se enfrenten. Este artículo estudia la controversia ambiental alrededor de uno de dichos megaproyectos, la vía férrea Konkan. El análisis emplea un marco que integra valores ambientales, creencias y comportamiento de individuos y grupos que tienen noción histórica de economía política y ecología. Discursos ambientales esencialistas y demasiado simplificados, sin credibilidad científica y que no están basados en hechos históricos, normalmente influyen en la formulación de políticas, especialmente cuando son conducidos por clases medias. Para una mejor comprensión de nuestras preocupaciones actuales y las políticas para manejar los problemas que enfrentamos, se requiere desenmascarar la romantización del campo. Debemos reemplazar la versión idílica del pasado con una matizada comprensión histórica de la interacción entre naturaleza y cultura. Este artículo también ubica la controversia de la vía férrea Konkan dentro de los acercamientos utilizados para estudiar el ambientalismo de la India. El objetivo consiste en mejorar nuestra comprensión de las pluralidades regionales, ideológicas y culturales en los valores ambientales, creencias y comportamiento de la clase media en India.

Palabras clave: grandes proyectos de infraestructura, Asia del sur, ambientalismo de clase media, desarrollo sustentable, controversia ambiental, romantización, racionalidad cultural

\section{Introduction}

Access to infrastructure is an important element of development. Post-independence India, however, has had its share of controversies around mega-infrastructure projects, which have pitted supporters of environmental preservation against development concerns. This is especially so in the case of megaprojects involving significant public investment such as dams, highways, railways, airports and nuclear power plants. On the one hand, such projects come with promises of substantial socioeconomic benefits in terms of economic growth, improved incomes and quality of life, increased livelihood opportunities, regional development and national integration. On the other, local objections against megaprojects claim environmental degradation, displacement, loss of livelihood, and disruption of the way of life of the affected community. Quite often in India, environmentalism becomes a proxy for critiques of modernity, which is closely aligned with the critique of a Nehruvian science and technology based "development paradigm" pursued by the Indian state (Alvares 1992b; Nandy 1988; Visvanathan and Nandy 1988).

The Konkan Railway (KR) project, which was completed in 1998, was mired in such an environmental controversy during its construction phase and was recently again identified as a "contested space of environment versus development" by an expert panel, commissioned by the Government of India (GOI), for the conservation and development of the Western Ghats (WG) region. The WG is the name given to a chain of mountains that run parallel to the western coast of India, traversing six states and covering around 140,000 $\mathrm{km}^{2}$ in a 1,600 km-long stretch. They influence the monsoon weather pattern in India and are globally recognized for a high level of biodiversity, endemism, and unique geomorphic features and biophysical and ecological processes. The Gadgil report, titled the Western Ghats Ecology Expert Panel Report 2013, headed by the environmentalist Madhav Gadgil said the following about the KR:

The Konkan Railway...is one such contested space of environment versus development, and impacts on coastal versus forest ecology.... The Railway has had a number of impacts, both on forest and coastal ecology, more on the latter because of its alignment and was much fought against in the state of Goa as it was expected to have, and has had, enormous impacts on coastal ecology, especially on mangrove forests, swamps and khazan lands. (Gadgil et al. 2011: 87)

The Gadgil report and its recommendations generated widespread discontentment among political figures, environmental organizations and citizens. In the polarised debate that followed its release, one section felt that the recommendations were not doing enough for environmental preservation while the other contested that they would stifle the development of the region (Nagarajan et al. 2015). This led to the GOI constituting another expert panel for the same objective, but with the additional mandate to review the content of the Gadgil report. 
As in recent years, the development and conservation of the Western Ghats region has gained prominence in the agenda of central and state governments, one of the objectives of this article is to understand the nature of environmentalism around mega-development projects in the region, in order to guide future policy-makers. It attempts to locate the Konkan Railway controversy within the frames used to study Indian environmentalism, so as to improve our understanding of the regional, ideological and cultural pluralities in environmental values, beliefs and behaviour of the middle class in India. In this respect it answers the call made by Mawdsley for more "empirically-informed consideration of the diversity and dynamism of the middle classes in relation to the environment" (Mawdsley 2004: 94).

\section{Methodology}

The framework employed to locate KR controversy integrates individual and group environmental values, beliefs and behaviour with a historical understanding of ecology (science) and political economy. Any attempt to study the political and ideological premises of environmentalism will require understanding of ideas of nature as is reflected in the framing of environmental problems and the reasoning employed by the stakeholders involved. That said, in understanding ideas of nature as they are articulated in environmental controversies, one must take care to avoid culturally relativistic conclusions and bear in mind that the natural world exists quite independent of our ideas about it. Moreover, such ideas about nature cannot be understood in isolation, as there is no distinct sphere of environmental values that stands apart from other values (Bauer 2015a). Rather ideas of nature are "dynamic, and contingent on specific social, legal, political and economic conditions" of the context within which they find articulation (Bauer 2015b: 2).

The research is based on a thematic analysis of archival data sources from the year 1990-2000. The controversy was covered in detail in leading English newspapers in India such as The Times of India, The Hindu, The Deccan Herald, The Pioneer, The Indian Express, The Telegraph, The Sunday Observer, and Business Standard. It was also covered as feature-length articles in a number of English language magazines such as The Frontline, India Today, The Week and those which exclusively dealt with environmental issues such as Down to Earth and The Hindu's Survey of the Environment Reports. One limitation of the data sources used is that they are limited to English language newspapers and magazines. Other vernacular language newspapers have the potential to bring out opinions and voices of more stakeholders. However, since English was the medium of choice for the social action groups and eminent Goans that were most successful in persuading the Government of India to suspend the work on Konkan Railway, these sources have the potential to capture the most dominant narrative around the Konkan Railway in Goa. The archives of the reportage of the KR in these newspapers and magazines, along with published letters from citizens, forms a part of the background material for this study. This is supplemented by the environmental impact assessment report of the KR, reports of various committees appointed to look into the KR controversy, court cases and material published by environmental organizations.

The article begins by charting the trajectory of the KR controversy. It then proceeds to make sense of it by integrating ecology, political economy, and ideas of nature in the analysis. The next section tries to locate the KR controversy within the two most commonly used frames for studying environmental controversies in India: 'environmentalism of the poor' and 'bourgeois or middle-class environmentalism.' The article concludes by outlining the broad contours of a normative framework to understand the politics around development and the environment, and how this can set the agenda for future research.

\section{The Konkan Railway controversy: varying local responses and the stakeholders involved}

The KR was built through the Konkan region, a part of India's western coastal strip lying in the WG, bounded by the Sahyadri hills on the east, and the Arabian Sea to the west (Figure 1). Though the first proposal for a railway line along the western coast was mooted as early as 1894, the difficult terrain posed several engineering challenges and the economic unviability of the venture prevented the project from taking off. It gained political momentum when two prominent leaders from the Konkan region, George Fernandes and Madhu Dandavate (from Karnataka and Maharashtra respectively) became Minister of Railways and Finance Minister, in the short-lived Janta Dal government from 1989-1990.

The KR, which traverses the states of Maharashtra, Karnataka and Goa, was proposed to significantly reduce the distance and travel time for the movement for freight and people between Mumbai 
and Mangalore and to spur socio-economic development in the region. The Konkan Railway Corporation (KRC) was set up in 1990 as a public sector body under the Ministry of Railways. Final surveys and construction began soon after and from 1993 onwards the KR was completed in phases from each end. The complete line of $760 \mathrm{~km}$ became fully operational in 1998.
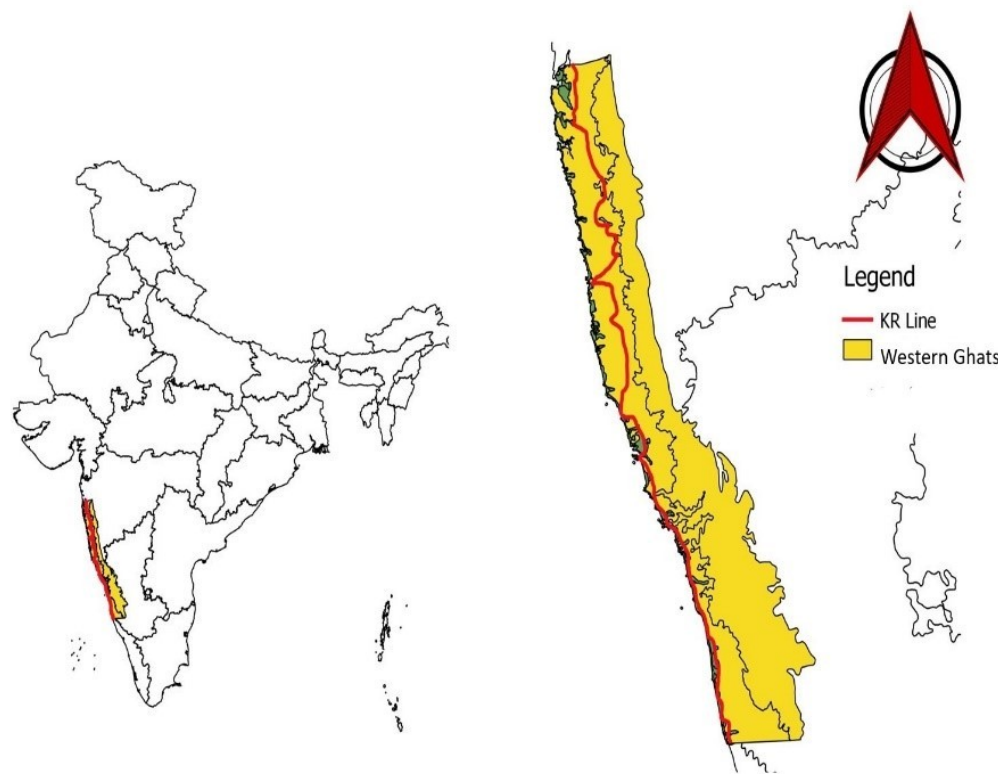

$\begin{array}{llllll}50 & 0 & 50 & 100 & 150 & 200 \mathrm{~km}\end{array}$

Figure 1: The Konkan Railway and the Western Ghats. ${ }^{2}$

For the KRC's first Chairman and Managing Director, E. Sreedharan, a reputed civil engineer and for other office bearers and engineers, the KR was an engineering marvel, built using the latest technology, a symbol of modernizing India and a matter of national pride (See Date 1994; Kumar 1996; Sardesai and D'Mello 1992; Sidhva 1996; Varadarajan 1992). It was described as the biggest railway construction project undertaken in independent India and through some of the world's toughest terrain. However, for the project proponents its socioeconomic possibilities were paramount. For Dandavate, Fernandes and others, it was a dream come true for the people of the west coast who had longed for a railway line. This was a project that would usher in an era of development of a hitherto backward region whose industrial and development potential has remained unrealized due to its isolation, and for the want of a transport network integrating it to the rest of the country. In the context of the balance of payments crisis being faced by India in 1991, with inflated oil import costs precipitated by the Gulf War, millions of dollars could be saved in fuel costs by reducing distances and travel times. The KR was, therefore, a nationalist project.

The KR also elicited different responses from the coastal districts through which it was supposed to pass, providing an interesting opportunity to explore how socio-economic context can influence the public perception of a megaproject and affect its reception. For example, the districts of Ratnagiri and Sindhudurg in Maharashtra are distinct from the coastal talukas (sub-districts) of Goa. Both regions have been characterized by out-migration for employment and education, earning the epithet of 'money-order economies' (postal money orders sent back home by earning members elsewhere). However, when it comes to socio-economic indicators, the Konkan districts of Maharashtra, with a long history of poverty and backwardness lag behind those in Goa which, even in the late 1980s to the 1990s, was among the more prosperous regions of the country. This could be the reason for different responses to the KR. In the context of Ratnagiri and Sindhudurg, a journalist observes:

\footnotetext{
${ }^{2}$ I would like to thank Kamal Murari for his help in preparing the map.
} 
With dense sprawls of lush green forests, mountainous roofs, clean and sunny coastal land, Konkan may best be described as one of the unsung paradises of this plateau state [Maharashtra]. But the picturesque topography ... are no consolation for the Konkan people living in acute poverty and chronic backwardness...But the people of Konkan are once again beginning to dream for their 'queen' has arrived Konkan Rani. In the true spirit of what the well-known Marathi poet, Mr Vasant Bapat, inspired by the new KR wrote, "Ali Konkan Gadi Dada, Ali Konkan Gadi" (Konkan's train has come, brother, Konkan train has come), thousands of Konkanis came out of their farms and left their fishing nets to throng the 52-km long railway line between Khed and Veer section...to witness the inauguration of the KR. As they waved at the occupants of the special train — what a bliss to see the train traversing their land but agony at not being on it — and danced in joy. (Iyer 1995)

In the Konkan districts of Maharashtra, enthusiasm for the railway and cautious optimism about the development it was going to bring, cut across classes (See Babu 1997; Fernandes 1993; Iyer 1995; Mhasawade 1998; Sharma 1996). This was in stark contrast to the reception of the project in coastal talukas of Goa. Goa is one of the smallest and more prosperous states of India and dependent on tourism, mining and remittances as income sources. The Portuguese ruled Goa for close to 450 years and it became a part of India only in 1961. The most vocal critic of the alignment was concentrated in the prosperous coastal talukas of Salcette, Bardez, Tiswadi and Mormugao.

The conflict was not so much about constructing the KR through Goa, but about the alignment chosen by the KRC. The demand was that the alignment be shifted to pass through the mining belt or the hinterland rather than coastal Goa. The intellectual leadership of the KR was derived from a combination of urban and rural middle-class Goans. The middle class participants in the KR controversy formed an amorphous grouping, resisting clear definitions and characterization. This is true of the middle class in India in general, as class in India is a "complex construct, which opens up difficult methodological and conceptual debates, not least because of vast social and regional diversity" (Mawdsley 2004: 87). This necessitates that any analysis of "who constitutes the middle classes, and what their environmental values, beliefs and behaviours may be, must be locally anchored", as they are embedded in specific cultural and historical conditions (Ibid). In the case of the Konkan Railway controversy, the composition of intellectual leadership on the ground and in the media, was mostly middle class professionals, with professional or business careers in the villages and towns of Goa. Others retained ancestral homes and properties in Goa while residing in metropolitan cities such as Mumbai and Delhi, given the long history of outmigration from the region. A number of them came together with NGOs such the Goa Foundation, to form the Konkan Railway Realignment Action Committee (KRRAC). Another citizen's group in favour of realignment was the All Goa Citizens Committee for Social Justice and Action (AGCCSJA) backed by the Catholic Church. Members of the Goa chapter of the Indian Architects Association also protested against the harm to the environment caused by the alignment chosen by KRC. The membership of KRAAC and AGCCSJA was largely university professors, economists, school teachers, architects, journalists, Catholic leaders, bureaucrats, chairpersons of think-tanks, lawyers, businessmen, hoteliers, management professionals, engineers and consultants (both migrant Goans and locals). They were joined by urban and rural based environmental activists and the founders and personnel of NGOs. Going forward, the term 'realignment lobby' is used to describe these groupings demanding a change in alignment of the KR.

Out of the $105 \mathrm{~km}$ of track passing through Goa, the realignment lobby raised concerns, particularly, with regards to the $55 \mathrm{~km}$ from Mayem to Balli. It was argued that the tracks would cause damage to the ecosystem formed by River Mandovi and Zuari, mangrove swamps, the Khazan lands (low lying estuarine lands managed through a traditional technique of tidal flow management), the wetlands, the wildlife sanctuaries, and the Carambolim Lake (famous for its migratory birds) and would generally be detrimental to ecosystem and ecological balance of the region (See Times of India 1992; D'Mello 1992; Jos 1997; Paul 1993).

For the realignment lobby, the coastal route of the KR was a nightmare. It was a scar across or knife piercing their idyllic landscape (Padte 1993), a "butcher's line" (Banerjee 1992) or a "Berlin wall" (Rahman 2013) dividing the people and countryside of Goa, fragmenting their community and endangering a way of life they hold dear (Rodrigues 1993). It raised questions of Goan identity, alleging that the line would significantly alter the socio-cultural life of the coastal communities. Aruna Rodrigues, a project management consultant and representative of the major groups opposing the coastal route, in an article 
penned for a leading English newspaper, argued that the KR issue touches upon "some of Goa's deepest concerns of self-definition." Further, she alleged "such projects affect whole peoples and we live perilously if we think we can repeatedly ignore legitimate and well-argued pleas for self-definition and an environmental and cultural integrity" (Rodrigues 1993). The realignment lobby also expressed fears that the railway would bring in immigrants, many of whom would end up in slums and squatter settlements spoiling the picturesqueness of coastal Goa (for concerns raised see for example, Alvares 1992b; D'Mello 1992; Panandiker and Ribeiro 1993; Rodrigues 1993; Shankar 1992b).

The opponents of the KR alignment objected to the acquisition of Khazan lands and the building of high embankments and bridges across them and the environmental harm to Carambolim Lake. They portrayed these as unique, stable natural and cultural systems. The Khazan are low low-lying, marshy mangrove swamps and mudflats found along the rivers, creeks and estuaries of Goa that were reclaimed from tidal inundation of brackish water by means of large bunds or dykes, drainage canals or rivulets and sluice gates by early Goan settlers. They were originally used for cultivation of paddy rice and for pisciculture, by regulating the water intake and discharge from the fields using the sluice gates. The Khazan system is considered to be at least a thousand years old or more, however due to limited archaeological evidence the exact time period for settled rice agriculture in Goa and the reclamation of Khazan lands has proven difficult to determine (Rubinoff 2001).

The environmental protests by the realignment lobby ensured that the project went through multiple stages of expert assessment. In June 1992, following representations from various social action groups and eminent persons of Goa, the Ministry of Environment and Forests appointed a thirteen-member Kamala Chowdhury committee to consider the environmental and socio-cultural aspects of the proposed KR alignment. The KRC refused to appoint members to this committee on the grounds that it consisted of people who were known to have taken an uncompromising stand against the alignment in Goa (D'Monte 1991). Eight members of the committee ruled in favour of the alignment chosen by KRC, while the remaining five submitted a separate dissenting report. This aggravated the protests and in early 1993, the realignment lobby - this time spearheaded by the Church - lobbied directly with the Central Government. Following this the Prime Minister Narasimha Rao ordered the stoppage of work in March 1993. A one-man commission was then constituted by the Central Government, headed by Justice G.L. Oza, to inquire into and submit a report on the issues raised by the environmentalists. The committee held several public hearings and submitted its report in June 1993, and like the other appointed committees approved the KRC route with minor modifications. It offered suggestions for environmental management and mitigation of environmental damage. The work on the KR was resumed in December 1993. The entire line was opened for traffic on $26^{\text {th }}$ January 1998.

Allegations of bias, ulterior motives, manipulation, and lack of thoroughness was attributed to the workings of both these committees by the realignment lobby. They also produced counter-evidence and counter-experts of their own, mainly Goan engineers, environmentalists, and town planners who were a part of the realignment lobby. The aim was to challenge the findings of the Kamala Chowdhury Committee and to depose in front of Justice Oza. However, in the KR controversy, it was acknowledged that the "paucity of hard, scientific data on the impact of the railway on the khazan lands, local settlements or forests, it is not clear how any considered opinion can be reached on the question of economic versus ecological trade-off" (Agarwal and Narain 1992).

\section{A framework: understanding cultural constructions of nature within the wider socio-political and economic contexts}

The divisions between the technical advice offered by expert committees and the counter-experts produced by the realignment lobby, cast doubt on whether science can be an impartial arbiter between the diverse and conflicting values and interests of various groups. What then is the way forward in minimizing and resolving such environmental controversies?

Literature from risk perception studies suggests that the reason for the protracted nature of environmental movements and controversies lies in the disparate registers of reasoning expressed by experts and citizens. In public-decision making, the proponents of the project resort to technical rationality, whereas the opponents employ cultural rationality ( Fischer 2000; Phadke 2010a; Plough and Krimsky 1987). To elaborate, technical rationality, employed by proponents, in this case the KRC, political figures and the judiciary in favour of the alignment frame the arguments in decontextualized and abstracted terms, 
and harness technical knowledge they believe to be based on sound science and reason. The focus then is on quantifiable impacts, empirical evidence, the scientific method, and expert judgments (Fischer 2000; Plough and Krimsky 1987).

Perhaps the best illustration of technical rationality is the judgement in favour of the KRC by the Bombay High Court in the case of The Goa Foundation and Another vs. The Konkan Railway Corporation. The Court said:

\begin{abstract}
In our judgment, the claim of the petitioners that the alignment would have devastating and irreversible impact upon the Khazan lands is without any foundation, and even otherwise, the extent of damage is extremely negligible and a public project of such a magnitude which is undertaken for meeting the aspirations of the people on the west coast cannot be defeated on such considerations. (The Goa Foundation And Another vs The Konkan Railway Corporation 1992)
\end{abstract}

The High court also appealed for the matter to be left to the "experts" and for reason to prevail as opposed to parochial concerns:

No development is possible without some adverse effect on the ecology and environment but the projects of public utility cannot be abandoned and it is necessary to adjust the interest of the people as well as the necessity to maintain the environment. The balance has to be struck between the two interests and this exercise must be left to the persons who are familiar and specialized in the field....It is beyond our comprehension appreciate as to how a rail line can be or a road can be constructed without travelling over the bridges constructed over the rivers, creeks or seas...We hope and trust that everyone will realise that providing a rail line is neither a political nor a religious issue but is undertaken for providing basic necessity of cheap and quick mode of transport. (The Goa Foundation And Another vs The Konkan Railway Corporation 1992)

The top officials of KRC also appealed to science and reason to make their case. They portrayed the damage to the environment as minimal and something that could be managed and mitigated by careful construction, technological solutions and sound environmental management techniques. For example, for the chairman of the KRC, the realignment was a 'purely political problem' as the alignment had been chosen after a cost-benefit analysis (Sardesai 1992). KRC also channelled technical reasoning for retaining the alignment, arguing that it was finalized with several technical specifications in mind such as maintaining a uniform gradient, and that any shift would involve a significant cost escalation and time over-run.

On the one hand, the court and the KRC appealed to an abstracted national interest, decontextualizing the impact of the alignment on Goa. On the other hand, the opponents were concerned with the implications of the project on their social life world. They employed reasoning that uses not only technical knowledge claims, but also draws on personal and emotional elements and subjective values (Fischer 2000; Phadke 2010a). Not only did the realignment lobby raise issues of Goan identity, large scale immigration, and loss of a way of life, but they also questioned the very idea of development - development at what cost, for whom and for what purpose?

The social and political interests of the affected community shape environmental explanations, not only depersonalized technical and scientific findings. The rhetoric in environmental controversies is very much embedded in the social, economic and political context in which people find themselves. It takes "unanticipated consequences to be fully relevant to near term decision making and trusts process over outcomes" as is evident in the statement made by a realignment activist (Fischer 2000: 132):

The argument that it will further delay the project does not hold good for the simple reason that another six months to review the feasibility of this alternative route is nothing compared to the lifelong harm that a hastily-conceived project can cause. (Rodrigues 1993) 
If it is agreed that the parties in an environmental controversy use disparate sets of reasoning, what then is the way forward for resolving such controversies or to prevent them? For Fischer, the challenge ahead "is not just more science, but rather how to better understand the interactions between science and ideology - technical facts and cultural values - and most importantly, how to integrate them systematically in a more comprehensive analysis" (1993: 123). Cultural rationality, he suggests, has to become an integral part of risk assessment (Fischer 1993, 2000, 1993; Phadke 2010a). To this extent calls are made for understanding how 'civic epistemologies' and cultural rationalities can be better enrolled in regulatory contexts (Jasanoff 2011; Phadke 2010a, 2013). This entails implementing procedural changes for more public involvement in decision making. It calls for incorporation of procedural norms such as transparency and participation in decision making to promote dialog between interested and affected actors in a controversy. The expectation is that this will reduce conflicts, enhance legitimacy and thereby improve the local uptake of a project. Institutionalization occurs through procedural reforms and innovations such as citizen courts, public hearings, and participatory technology assessment which would enable deliberation. Others suggest going beyond such technical approaches and emphasize that "ideally, deliberative models [should] involve citizens in all phases of public policy, including research and discovery stages, to avoid parochial NIMBY responses to policy decisions" (Phadke 2010b: 5).

The question remains whether a better, more transparent deliberative model with greater public participation can enable consensus? Would the procedural reforms also lead to substantive outcomes that are just? It is important that these questions be asked, as there is the danger that in trying to resolve an environmental controversy like the KR through such deliberative models, might only lead to an intersubjective understanding of development that ignores material realities. In India calling for integrating technical and cultural rationality through dialogue and communication must not lead to a relativistic muddle, as so many environmental controversies have become. Prioritizing discursive practices for resolving disputes around development and preservation of the environment might often end up focusing on the self-understanding that actors in the controversy bring. Dialogical possibilities address this selfunderstanding of individuals, communities and other stakeholders in order to come up with solutions. But they can under-prioritize 'knowable reality' which provides stronger ontological grounds in understanding the challenges of environment and development.

What is needed is a framework for understanding environmental controversies which integrate ideas about nature, with political economy and ecology in order to avoid being trapped by false dichotomies created by looking at such questions in isolation (Worster 1990). For example, both the reports on the preservation and rejuvenation of the Western Ghats share the drawback that they do not fully consider the impact that their recommendations for preserving the Western Ghats will have on different activities. These include mining, power generation and energy, land use, human settlements, transport, tourism and agriculture and the overall economy and human development in the region. Nagarajan et al. (2015) consider the absence of a detailed demographic analysis as a serious shortcoming of the two reports. Using taluka and village level population and employment data of the region, they compare both on the question of who are the people being affected by the expert panel recommendations, and how will they be affected? They draw attention to the fact that they fail to address the concerns of cultivators; the threat of unemployment faced by labour employed in various industries in the region; and the concerns over livelihoods and income opportunities of a significant proportion of the population. The imperative of development for State governments is unacknowledged. They remark that "the absence of detailed demographic analysis of the affected areas in both reports cannot be regarded as simple oversight, since the very numbers would starkly pose the question of the impact of their recommendations on such large numbers of citizens" (Nagarajan et al. 2015: 53). They conclude this oversight is the result of the inadequate analytical framework adopted by the two reports. While enumerating environmental concerns, the two reports overlook society-environment interactions and economic issues. This clearly manifests itself in their inability to consider how the regulations and recommendations made for safeguarding environmental concerns will impact the socioeconomic development of the region. While recommending restrictions on large-scale projects like dams, power plants, roads and railways in certain sections of the ecologically sensitive zones, there is an absence of serious discussion of its implications for the socioeconomic development of the region.

A framework that understands the various cultural constructions of nature within the wider sociopolitical and economic contexts is needed, while also being attentive to ecological dynamics (Cronon 1990; Worster 1990). 


\section{Making sense of the Konkan Railway controversy: integrating ideas, political economy and science}

\section{Putting the Khazan and Carambolim Lake in historical perspective}

A closer examination of the environmental history of the Khazan lands and Carambolim lake show that far from being stable and balanced systems, as argued by the realignment lobby, they have undergone complex interactions with the environment and the economy. With respect to the Lake, Claude Alvares, an environmentalist and secretary of the Goa Foundation (an environmental NGO) said "Carambolim Lake is still an untouched biotic system full of natural predators in the balance and subject to a system of filtering that has maintained the purity of the water for centuries" (Alvares 1992b). However the Lake, situated in Tiswadi taluka, is far from being an "untouched biotic system." It is a human-made wetland and is classified as such by the Wetland Directory of India (Wetland Inventory n.d.). It is one among a number of minor irrigation schemes that have been developed in Goa for cultivating paddy rice. Spread over 70 hectares, it impounds runoff during the monsoon. It is also used for harvesting fish and is recognized as a major resting ground for migratory and local species of birds which come to the lake in the winter months of November to January. In 1991, the government of Goa declared the Carambolim wetlands a bird sanctuary under the Wildlife Protection Act. Before the start of the controversy, the lake had already been facing several problems including private encroachments, the dumping of garbage and waste in and around its waters, contamination by night soil generated by the lake's 'floating population', and continuous silt deposition leading to marshy conditions (Shanbhag, Walia and Borges 2001).

The Khazan lands were variously described by the realignment lobby as an "engineering feat", an "engineering marvel", and an "example of human ingenuity" (Alvares 1992b; Da Silva 1992; Gadgil and Chandran 1993). The Khazan system was depicted as having existed in equilibrium for thousands of years even, before the Portuguese conquest of Goa, as is evident in the statement made by Alvares: "This land has been cultivated over hundreds of years. Destroying it would finish the priceless ecological heritage of Goa" (Sardesai and D'Mello 1992: 11). He also wrote that "hitherto nothing has come between the tides and the land except the bunds and sluice gates. Now the KR line is scheduled to cut right through the Khazan lands, from north to south" (Alvares 1992b).

However, over the years the Khazan land management system has also undergone a number of institutional changes and broader interactions with the economy (D'Cruz and Raikar 2006). In the precolonial era the Khazans were controlled and managed on a cooperative basis by the village community, descendants of the original settlers (gaonkars) of a village (gaon). The Portuguese introduced changes in the functioning of the goankaria and rechristened it as a communidade, redirecting the agrarian surplus to the Portuguese (D'Cruz and Raikar 2006). After liberation, the national and later the state government introduced several new legislations. It enacted the Agricultural Reforms Act (1964) which granted land tenure to the tenants, and the management of khazans became the responsibility of the Tenants Association.

Even in colonial Goa the damage to the coastal Khazan lands due to breaches in the protective embankments was a serious issue (Kamat 2010; Talukdar 1962). The opening of private mining leases during the period between 1946-1961 led to a rise in volume of the iron ore exported - from sixty thousand metric tonnes in 1946 to six million metric tonnes in 1961 (Talukdar 1962). This led to deforestation of mining areas and the resultant erosion caused the silting of rivers and of the Khazan lands. The bigbottomed barges transporting the mineral ores produced waves in the river system which led to frequent breaches in embankments and the collapse in the bunds protecting khazan lands against saline water (Kamat 2010). Similar observations were also made by the Goa Land Reforms Commission, that was appointed in 1963 and headed by A.L. Dias. Additionally, the Dias Commission observed that quite an appreciable amount of Khazan land had gone out of cultivation and financial difficulties made it difficult for the communidades to the maintain bunds and the lands (Vanjari 1968).

By the 1990s, the revenue from paddy cultivation in the Khazans using traditional seed varieties was also on the decline, as yields were low. Moreover the process was too labour intensive; and a shortage of agricultural labour in Goa made hiring farm workers expensive (Bose 2007; Shankar 1992a). Since pisciculture was a more profitable venture than paddy cultivation, khazan owners intentionally breached the bund to inundate it with saline water to carry out fish farming, especially shrimps and prawns which fetched high prices in the market. When the problem of intentional flooding became acute, in 1991 the state government enacted a law which prohibited the conversion of agricultural khazans for pisciculture unless 
they had been lying fallow for at least five years. This regulation failed to have the desired effect as it only encouraged prospective prawn cultivators to collude with landlords, tenants and village officials to obtain false land-use certificates (Shankar 1992a).

These are only the broad contours of the changes the Khazan lands and the Carambolim Lake have undergone. It is beyond the scope of this article to undertake an exhaustive review of all the changes and interactions. However, one may safely assume that the depiction of Khazan as a balanced and eco-friendly agro-ecological system devised by so called self-contained village communities that were themselves also stable, seems essentialist and ahistorical on closer examination. It denies the dynamism of the natural and cultural systems.

New traditionalism and romanticization in the historiography of the environment: unpacking the rural idyll

The realignment lobby in the KR controversy often juxtaposed expert knowledge and modern ways of knowing with local knowledge and wisdom. Alvares, for example, in reference to the Khazan states that "no modern development agency or government department would have come up with such an amazingly efficient and productive system" (Alvares 1992b). This reveals that primitive and local ways of knowing nature are held in respect and admiration and modern ways of knowing nature are depicted at inadequate at best. Reverence for the so-called innate wisdom of local people is also evident in Gadgil's account of the Khazan lands:

In Goa...the villagers have been managing these sluice gates for generations and know the nuances of the water flow. There has never been any scientific study of this circulation and no technical expert really knows what goes on. It therefore makes abundant sense to involve the local people in deciding how best to manage the flows if ... railway track...is going to obstruct it. (Gadgil and Chandran 1993)

This is also accompanied by a very specific reading of pre-colonial society as marked by harmonious relationships with the environment, and by the glorification of the wise and ecologically sensitive use of resources by early settlers of Goa. Members of the realignment lobby argued that the khazans form part of Goa's civilizational history, emblematic of its peoples' successful interaction with the natural systems and the fine balance they created between land, water and humankind (Alvares 1992b, 2002; Panandiker and Ribeiro 1993). Nazar Da Silva, prominent resident of Moira village in Goa, in a letter to the Times of India, wrote that:

...over the course of centuries they [ancestors] have nurtured low-lying Khazan land. They reclaimed it from the sea with ingenious bunds and sluice gates and thus created productive, eco-friendly occupations of agriculture and salt-panning. The work of centuries is now threatened with doom. Heritage and culture must be viewed in this perspective. (Da Silva 1992).

Such a framing forms a part of the "new traditionalism", a discourse that has dominated the historiography of the environment in India for some time. It asserts that the traditional societies were ecologically balanced, self-contained and practiced traditional agriculture. Alongside, it claims that local people are primarily the keepers of a special conservationist ethic and that interchangeably colonialism, modernity and development were exclusively responsible for the degradation of nature in India (Sinha, Gururani, and Greenberg 1997) .

Another recurring theme among the realignment lobby was the romanticization of the Goan countryside. For them what was at stake was integrity, peace and tranquillity, the Portuguese heritage and the way of life of Goan villages and communities. A member of the KRRC stated that "The railway line will destroy our villages and make them into mini-slum pockets" (Sardesai and D'Mello 1992); Ralino de Sousa, chairperson of the Goa chapter of the Indian Architects Association, said "Goa's villages and towns are thickly populated and the railway line will split many of them. It will certainly add to congestion and harass the people." (Shankar 1992b). According to V.A. Pai Panandikar, originally from Goa and then the 
director of a think-tank based in New Delhi, "the proposed alignment will destroy a whole civilisation built over 3,000 years. Only small technical minds will be impervious to the larger and incalculable costs of disturbing the societal ecology, including division of this most vital and sensitive, Salcette taluka" (Rodrigues 1993). Another local said that "from a paradise we'll degenerate into slums and the slums will give rise to diseases. Goa's tranquillity will be lost forever" (Paul 1993).

This characterization of the Goan countryside as a paradise is not quite the same as the characterization of pre-colonial villages in new traditionalist discourse. The new traditionalist discourse characterizes villages as socially and ecologically stable, self-sufficient, self-governing decision-making and resource management units, uninfluenced by external political and economic forces (Sinha, Gururani, and Greenberg 1997). Whereas the roots of this discourse are to some extent in Gandhian philosophy and Gandhi's dream of India as a land of village republics, the characterization of the Goan countryside as a paradise traces its roots to Portuguese cultural influence in Goa.

As already pointed out, the most vocal criticism of the alignment was concentrated in the coastal talukas of Salcette, Bardez, and Tiswadi. Together these talukas form the region known as Velhas Conquistas or Old Conquests which were the first to be incorporated in Portuguese India in the sixteenth century. These areas, conquered by 1533, came under the direct rule of the Portuguese king and it is in this region that a distinct Goan identity was shaped through 450 years of European political, social and cultural domination (Kale 1986: 909). In the context of the cultural influences it engendered, Kale writes:

The City of Goa was the supreme spatial symbol of the Goan cultural synthesis. It was Golden Goa, the Rome of the East and a cosmopolitan urban centre- the seat of a sea born empire of Estado da India [The State of India] ...The Goan countryside, on the other hand, represented a primordial Garden of Eden and earthly paradise to which migrant Goans looked back with longing. Like the Biblical Eden the Goan paradise was pre-Christian. People lived here in a state of natural grace. The City of Goa and the picturesque Goan countryside are two distinct, yet complementary spatial elements of the Goan self-image and world view. (Kale 1986: 2057)

This sentiment of Goa as an earthly paradise which the KR will ruin, was reflected in an article written by the eminent Goan, author, columnist, diplomat and a Catholic leader based in Mumbai, George Menezes:

My father...must be turning in his Goan grave as he watches the despoliation of his fatherland by a railway line...The catalogue of the sins of the Konkan railway line is endless.... I dream of bunking classes and spending entire days watching with school boy fascination the opening and closing of simple wooden sluice gates at the ebb and flow of the river that circles around my native island of Divar like a halo of grace and goodness. I dream of mangoscented, caju-laden groves where, at dusk on the hills behind our house... I wake up to a nightmare of paddy fields barren and brown, of green hills sold to railway contractors, shuddering in the arms of massive bulldozers, violated forever, of a fishing community wiped out, the laughter of fisherwomen in our markets finally stilled, of mosquito nets in villages and even the central Asian birds no longer flying over the Himalayas to seek haven in the bird sanctuary of Carambolim. Can I tell my father, "Dad, Goa is no place for fish or bird or beast? Only a place for men standing in endless corrupted queues to buy a railway ticket for a train to nowhere? (G. Menezes 1992)

This statement shows how the realignment lobby constructed an image of the Goan countryside as a "rural idyll", imagining a place of peace and tranquillity, of simple virtue, of agrarian simplicity and verdant lands (Short 2006; Woods 2010). The rural idyll is defined in this statement not just by its landscape but also by the everyday practices of rural residents like the fisherwomen. It is contrasted with the artificiality, corruption, social destabilization and the environmentally destructive influence of modern technology and modern living.

Further, the realignment lobby also raised concerns that the railway alignment will endanger the way of life of the people of the state. According to another realignment lobby leader, "the coastal route will quite 
simply destroy whole villages and the entire fabric of life of the state" (Rodrigues 1993). According to a Goan business executive "It is our sossegado lifestyle that is threatened" (Burns 1994).

Sossegado or susegad as it is more commonly referred to by the people of Goa in Konkani language, comes from the Portuguese word sossegado which means calm or serene. In Goa, it generally refers to the laid-back attitude that is supposedly inscribed in the Goan cultural psyche and has been engendered through 450 years of Portuguese rule. Maria Teresa Menezes, author of The essential Goa cookbook, describes it thus: "the Portuguese...gave to Goa that very special quality distilled from Iberian indolence, that distinct attitude of sossegado that sets Goans apart from other Indians" (M.T. Menezes 2000: 11). She describes the pace of life in Goa and the people themselves as sossegado. She writes that "pace of life in Goa remains sossegado - relaxed, unhurried, seductive, balm to the soul" (Ibid 2000: 23). Further, Goans "are courteous and hospitable, appear well content with life, not driven by modern demons, in a word, they are sossegado - laid back rather than lazy" (Ibid 2000: 8).

The references to susegad or contented lifestyles of the people of Goa, are in sharp contrast with the people's history of migration for better income, employment and education opportunities. According to the Goa migration study 2008 (2008), 12\% households in Goa had an emigrant living abroad and another 4\% were return emigrants (defined as members of the household who had emigrated out of India but have since returned and were members of the household during the Survey). The Old Conquests talukas accounted for most emigrant households, with of Salcette Taluka accounting for 50 per cent, followed by Bardez and Tiswadi Talukas with 15 per cent each.

The history of migration from Goa can be divided into three phases (Gracias 2000; Kale 1986, 1994). The first phase was between the $16^{\text {th }}$ and $17^{\text {th }}$ century and was an outcome of the over-zealous religious policy of the Portuguese, which forced a number of Hindus and later newly converted Christians to migrate. The second phase between the late $18^{\text {th }}$ and early $19^{\text {th }}$ century was of a socio-economic nature (Gracias 2000; Kale 1986). This was an outcome of several factors. Among these were the British occupation of Goa during the Napoleonic wars, and the decline of Portugal as a colonial power and the consequent stagnation of the Goan economy (Gracias 2000; Kale 1986, 1994). Accompanied by the improved means of transport and communication, it spurred large-scale migration, primarily from Old Conquests, to British India (mainly to Bombay, Karachi, Pune), Africa and the Gulf. This was spurred by the high cost of living, unemployment, and the lack of educational facilities in Goa (Gracias 2000; Kale 1986). This phase, resulting from economic stagnation, has continued into the 21st century and is not confined to any particular caste or class group.

Goa's high rate of emigration has had a major impact on Goan identity. The themes of yearning to return to the village and the importance of family and ancestral home, are important elements of the Goan identity and this is extensively explored in literature and other writings on Goa (See for example Sardessai 2000; Simoes 1998; Wagle and Coehlo 1995). For the migrant Goans, it was important to maintain the dream of returning to their homeland. The dream includes maintaining, or acquiring a home not only for themselves, but also for their descendants. Migrants earning good wages save money which they invest in buying land and building houses back in their villages. Ancestral home is one of the most prized possessions for the Goan migrant.

Just as references to sossegado found in Goan villages is in contrast with the history of migration, the primitive utopia of Goan countryside as an earthly paradise and the khazans as an eco-friendly and stable agro-ecological system is in contradiction with its history of economic stagnation, and declining profits from agriculture. As far as the economy of Goa was concerned, during their 451 year rule, the Portuguese did not make any substantial capital investment and made no significant effort to industrialise Goa (Talukdar 1962). They focused instead on mining, which supplied the Portuguese with large amounts of foreign exchange. Iron ore mining was mechanized in 1951, and a large number of mining leases were granted, increasing the pace and scale of mining in Goa. This also resulted in a shortage of agricultural labor that could earn better wages in the mining areas and in the cities than in agriculture under the antiquated feudal system of land tenure system in Goa (Ibid). After liberation the government enacted a number of tenancy reform acts, but agriculture had ceased to be profitable. There has been a spate of land conversion in Goa and by the 1990s, 65-80\% of lands were being used for non-agricultural purposes (D'Cruz and Raikar 2006; Navhind Times 2003). Apart from the institutional arrangements, other factors contributing to decline in agriculture were expensive labor, out-dated methods of cultivation, inadequate irrigation facilities all of which accounts for the low yield per acre and the consequent deficit in food grains (Talukdar 1962). During Portuguese rule, British India and later the Government of India provided a 
substantial proportion of Goan imports, including food-grains and other necessities (Ibid). Postindependence Goa is also heavily dependent on neighbouring states for food grains, cereals, vegetables and milk (Shankar 1992a).

The social stratification of Goan society, the migration of Goans in search for better income, employment and education opportunities, its economic stagnation and agricultural decline, and its dependency on neighbouring states for food grains, are emblematic of a serious disconnect between the idyllic representation of rural life and the realities of Goan socio-economic conditions. Its depiction of stable and self-sufficient rural communities also obscures the interaction between the city and the villages for livelihood and commodities. In their idyllic representation of rural society, the realignment lobby also failed to see the 'rural' as a space of production beyond just subsistence farming and other primary industries. The KRRAC and other activists had proposed an alternate alignment for the KR which would pass through the state's mining areas on the ground that the forests in this area were already degraded. KRC and some political figures argued that were the alignment to pass through the mining areas, iron ore along the route could not be extracted, and this would entail a significant loss to the state exchequer (Agarwal and Narain 1992; Shankar 1992b). This proposal for an alternative alignment by realignment activists framed mining as an environmentally destructive activity, but without any deliberation on the loss of income and employment opportunities such a change would entail. They failed to see mining as an economically productive activity providing livelihood to a significant number of people, including migrant workers and generating revenue for the state exchequer.

\section{The Konkan Railway controversy and middle-class environmentalism}

A number of scholars have characterised environmental movements in India as the "environmentalism of the poor" (Guha and Martínez-Alier 2013). According to this characterization, in contrast to environmentalism in developed countries driven by post-materialistic concerns, environmentalism in India is more about material distributive justice (Baviskar 2011). It is about resisting displacement by state-led infrastructure development initiatives and by private industries. It is about the protection of livelihood, and defending the rights of forest dwellers, adivasis, small farmers and fisherfolk to access land, water and forest resources. It combines green elements of environmental protection along with red elements of equity and justice (Guha and Martínez-Alier 2013).

A more recent addition to this schema is what Baviskar has termed "bourgeois environmentalism" (Baviskar 2011). Whereas the locus of the environmentalism of the poor is rural, bourgeois environmentalism is a typically an urban phenomenon, where the urban middle class driven by their concerns of health and hazard, beauty and order, channel state institutional and legal machinery for cleanliness and beautification of the city (Baviskar 2011; Baviskar, Sinha, and Philip 2015). In bourgeois environmentalism these concerns take precedence over issues of life and livelihood of poor and vulnerable groups like hawkers, daily wage laborers and industrial laborers (Baviskar 2011).

As already elaborated, the realignment lobby consisted of rural and urban middle class Goans and Goans settled outside Goa, retaining ties and/or having ancestral homes in Goa. The realignment lobby pursued strategies for their cause which were a hybrid of those followed by bourgeois environmentalists and in the environmentalism of the poor. Whereas the former use their privileged access to the media and the courts, the latter, due to lack of resources, are more likely to use direct action. The participants in the KR controversy wrote individual columns in India's leading daily English newspapers and prominent magazines and they regularly spoke to journalists, and had their views quoted by them. They also wrote letters to the media houses and to the editors to express their stand on the issue and in response to those articles which they disagreed with. They undertook persistent letter-writing campaigns to the central government and lobbied political figures. Along with using their privileged access to the media, they also used the substantial resources at their disposal to approach the Goa Bench of the Bombay High Court multiple times through writ petitions against the KRC. In April 1992, Alvares of the Goa foundation filed a writ petition before the Goa bench of the Bombay High Court, on the grounds that a satisfactory EIA had not been done before the KRC began construction. This petition was dismissed by the Court. In early 1993, the realignment lobby spearheaded by the Church lobbied directly with the Central Government. The Archbishop of Goa met the Prime Minister Narasimha Rao, after which the stoppage of work in March 1993 was ordered. At the same time, they pursued some direct action, primarily because of the involvement of grassroots NGOs like Goa Foundation. This included traffic blockades and courting arrest, holding fasts, 
picketing, forming human chains, demonstrations, driving away KRC workers, and burning down the hutments of laborers.

When it comes to environmental values, beliefs, and priorities, Baviskar (2011) recognises a contradictory consciousness among the middle classes, as a defining feature of bourgeois environmentalism. She argues that whereas the urban bourgeois environmentalists are embedded in modernity and aspire to live in clean, safe, planned and ordered "world class cities" with modern infrastructural amenities, they either misrecognize or are unreflective of their own complicity in creating urban environmental problems, through their own resource-intensive, consumerist and affluent lifestyles (Baviskar 2011).

Superficially this does not seem to be the case with the social grouping of the KR controversy. The realignment lobby was critical of modern lifestyles and modern technology, and it sought to produce a hegemonic notion of the paradisiacal, timeless, self-sufficient, ecologically stable, peaceful and harmonious rural idyll. Some of them like Claude Alvares also self-consciously practice living "sustainably" (Alvares 1992a). That said, the opponents of the KR alignment did display a contradictory consciousness when it comes to preservation of the environment. This is evident in their recommendations for alternative alignments. One suggestion was that the alignment should pass through the hinterland, through the forested areas at the foothills of the Western Ghats. Though the actual forested area that would have to be cleared for this alignment was under dispute, it was recognized that it would be considerably more than the coastal route. However, the environmentalists were willing to make this trade-off in favour of greater loss of forest cover and ecological damage to the hinterland than ecological damage to the coastal areas, possibly because of the greater environmental and cultural heritage value they attached to the environment of the coastal talukas.

Significantly, the commonality between bourgeois environmentalists and the rural and urban middle class environmentalism of the realignment lobby is the conscious or unconscious anti-poor, anti-slum dweller orientation, along with a disdain for unorganized workers. For the urban bourgeois environmentalists, the solutions to their concerns pertaining to the urban environment, such as air and water pollution, creation of a planned orderly city at the cost of loss of livelihood for industrial and migrant workers and daily-wage laborers. The concerns of workers about work, health and safety were superseded by bourgeois environmentalists who projected environmental issues such as air and water pollution as transcendental issues of 'public interest' (Baviskar 2011; Baviskar, Sinha, and Philip 2015). The alternative alignment passing through the state's mining areas, placed priority on preserving the rural idyll, failing to see the rural as an economic space. Consequently, they displayed a lack of concern with livelihood impact on mineworkers. There was also hostility towards an influx of migrant workers into Goa and the slums, and the noise and over-crowing and filth the KR would bring in its wake, all contributing allegedly to the despoliation of the Goan countryside (Shankar 1992b).

\section{Interrogating middle class environmentalism}

The urban and rural middle class-led KR controversy adds to our understanding of diversity in the ideological, political, regional and cultural premises of environmentalism in India. It is important that researchers should concern themselves with the environmental values, beliefs and behaviours of India's middle classes. Firstly, the middle classes "exert a disproportionate influence in shaping the terms of public debate on environmental issues through their strong representation in the media, politics, scientific establishment, NGOs, bureaucracy, environmental institutions and the legal system" (Mawdsley 2004: 81). This is visible in the case of the KR, where the participants used their privileged access to the media, judiciary and political figures to advance their goals.

Secondly, there are growing indications of dynamism and change in terms of the understandings of, and anxieties around, various environmental issues, and "these indications of a growing 'environmental' consciousness are not necessarily positive - either for environmental improvement (however that might be defined) or for the poor" (Mawdsley 2004: 82). This was especially the case with environmental activism of the realignment lobby who show tendencies that were strongly anti-poor, anti-migrant, anti-unorganized workers, and anti-slum dwellers. Moreover, the romanticization of traditional rural societies by middle class environmentalist glosses over the oppressive class and caste relations within which subsistence lifestyle and culture is placed (Pieterse 2000). When the traditional rural communities' relationship with the environment is romanticized as stable and environmentally conscious, it diminishes the importance of 
efforts for making tangible improvements in rural livelihoods, or modernization of agriculture. This could have repercussions for rural development policy because, for all the romanticization, life in rural areas in India is far from idyllic. There is a lack of access to resources - basic facilities like transport and communication, sanitation, power, medical and banking infrastructure and there is poverty, deprivation and caste, class and gender discrimination.

Thirdly, exploring the ways in which the middle classes conceptualize and behave in relation to the environment is critical in order to "reflect on much wider changes within India, including industrialization processes and policies, social relations, urban governance and so on" (Mawdsley 2004: 81). Analysing the middle classes, puts us "in a better position to think about the poor, and the relationships between environmental and social justice" (Mawdsley 2004: 81). This insight suggests that the unpacking of ideologies and assumptions of the rural and urban middle class in the KR controversy cannot be seen in isolation. Nor can we engage with debates about environmental preservation without adequate attention to issues of industrialization and socio-economic development in western coastal India. Essentialist and ahistorical arguments, as we have seen in the case of the KR controversy, obscure and foreclose debate on a number of pertinent aspects of the Goan political economy, such as economic stagnation, agricultural backwardness and outmigration driven by socio-economic factors. It therefore it hides as much as it reveals.

Demands were raised by the realignment lobby, such as the local communities of Goa's "right to decide about the use of their environment and to opt out of the estimated benefits of any development project" (Agarwal and Narain 1992), or to decide if they "want the project or not; whether they want modernisation or not" (Dubashi 1993). This was accompanied by calls for decentralization of decisionmaking and warnings such as "the history of development in the country is replete with examples of how the lack of proper planning and people's participation in this process has cost us dearly" (Rodrigues 1993).

Questions do have to be asked about whether they have a right to reject a development project in order pursue their ecological heritage or cultural heritage, or to opt out of the estimated benefits of any development project. But these questions will have to be asked beyond the discursive level of ideas around nature and development and within the broader context of political economy, science, public reasoning and environmental governance. The same applies to calls for decentralized decision-making. This is because, in India, there are no homogenous local communities; they are riddled with caste, class and gender discrimination. Moreover, as Nagarajan et al. (2015) argue

...we are witnessing selective appeals to the "will" of the people or communities. In fact, communities are also selectively identified or located. The levels of governance to be included in the decision-making process are often arbitrarily identified. Very often the Government of India and environmental movements and NGOs concur in trying to exclude state governments or local governments while issuing ambiguous appeals to decentralisation. Such attempts to reinterpret the meaning of democratic processes are common to proenvironmental movements, groups and advocates, as well as the powers-that be in Delhi. (Nagarajan et al. 2015)

There is no doubt that the principles and practices of participation, equitable resource use and ecological responsibility will have to be discursively arrived at through a process of social struggles and political renegotiation around environmental and developmental concerns. But at the same time any framework for understanding development will have to engage not only with ideas about nature, but also with the empirical and historical, and combine scientific understanding of environmental problems with values and ethics.

\section{Conclusion}

This study is an attempt to make an empirical contribution towards our understanding of the regional, ideological and cultural pluralities in environmental values, beliefs and behaviour of the middle class in India. Essentialist and over-simplified environmental discourses, not based on historical facts and lacking in scientific credibility, can be influential in policy-making, especially when channelled by the middle classes. The question to ask. however, is if such discourses around natural and cultural systems can serve as good guides for protecting the environment, as they tend to obscure the oppressive circumstances within which subsistence lifestyle and culture is placed (among other elements). 
It can be argued that environmentalists engage in such ahistorical and essentialist arguments as a rhetorical and political strategy in order to gain supporters for the environmental cause, and that by challenging these assumptions one would weaken the larger political movement for environmental protection. However, as Cronon argues,

If the grounding assumptions of modern environmentalism are susceptible to criticism for being historically naive, then surely they deserve to be criticized. We shouldn't evade that task for fear that it will weaken the larger political movement, since any movement worth defending - as environmentalism surely is - can only be strengthened by fostering rigorous critical analysis and debate. (Cronon 1993: 12)

Hence it follows that, just as it is important to interrogate the ideological and political premises of mainstream development discourse (a strategy which is the hallmark of environmental discourse in India) (Sinha, Gururani, and Greenberg 1997), in the same way middle class environmentalism discourse also needs to be interrogated for its political and ideological premises and its implications.

\section{References}

Agarwal, A. and S. Narain. 1992. Govt, Konkan Rail deaf to Goan cries of 'NIMBY.' The Economic Times, October 18.

Alvares, C. 1992a. Preface. In Science, development and violence: the revolt against modernity. Delhi: Oxford University Press.

Alvares, C. 1992b. The Great Konkan Railway Bazaar: environmental catastrophe. Sunday Observer, June 14.

Alvares, C. 2002. Fish curry and rice. The Other India Press.

Babu, Hemant. 1997. Dreams ride on the Konkan Railway. Indian Express, October 11.

Banerjee, Indranil. 1992. On the wrong track. Sunday, April 29.

Bauer, J.R. (ed.). 2015a. Forging environmentalism: justice, livelihood, and contested environments. London: Routledge.

Bauer, J.R. (ed.). 2015b. Introduction. In Bauer, J.R. (ed.). Forging environmentalism: justice, livelihood, and contested environments. London: Routledge: 1-21

Baviskar, A. 2011. Cows, cars and cycle-rickshaws: bourgeois environmentalism and the battle for Delhi's streets. In Baviskar, A. and R. Ray (eds.) Elite and everyman: the cultural politics of the Indian middle classes. New Delhi: Routledge. 391-419

Baviskar, A., S. Sinha and K. Philip. 2015. Rethinking Indian environmentalism: industrial pollution in Delhi and fisheries in Kerala. In J.R. Bauer (ed.) Forging environmentalism: justice, livelihood, and contested environments. London: Routledge:189-256

Bose, I. 2007. Goa's disappearing Khazan farms dying a slow death. Down to Earth, June 15.

Burns, J.F. 1994. Panaji journal: a pocketful of Portuguese, and new intruders. The New York Times, May 3.

Cronon, W. 1990. Modes of prophecy and production: placing nature in history. The Journal of American History 76(4): 1122-1131.

Cronon, W. 1993. The uses of environmental history. Environmental History Review 17(3): 1-22.

Da Silva, N. 1992. Injustice to Goa. Times of India, May 21. sec. Letter.

Date, V. 1994. Race against time on difficult terrain. Times of India, March 15.

D'Cruz, S. and A.V. Raikar. 2006. Democratic management of common property in Goa: from 'Gaonkarias' and 'Communidades' to Gram Sabhas. Economic and Political Weekly 41(5): 439-445.

D'Mello, A. 1992. Konkan Railway project damages Goan ecology. Times of India, May 31.

D'Monte, D. 1991. Committee splits on Goa route. Times of India, December 1.

Dubashi, J. 1993. Narmada, Konkan Railway, Chilka: The people have spoken. Sunday Observer, April 11.

Fernandes, A. 1993. A West Coast dream takes shape. Times of India, July 21. 
Fischer, F. 1993. Citizen participation and the democratization of policy expertise: from theoretical inquiry to practical cases. Policy Sciences 26 (3): 165-87. https://doi.org/10.1007/BF00999715.

Fischer, F. 2000. Citizens, experts, and the environment: the politics of local knowledge. Duke University Press.

Gadgil, M., B. Krishnan, V. Vijayan, R. Borges, R. Sukumar, and G. Subrahmanyam. 2011. Report of the Western Ghats Ecology Expert Panel: Part 1. Ministry of Environment and Forests, Government of India.

Gadgil, M. and M.DS. Chandran. 1993. Konkan lessons: a railway project and the environment. Frontline, March 26.

Goa Migration Study. 2008. Department of NRI affairs, Government of Goa.

Gracias, F. da Silva. 2000. Goans away from Goa: migration to the Middle East. Lusotopie 2000: 423-432.

Guha, R. and J. Martínez-Alier (eds.). 2013. Varieties of environmentalism: essays North and South. London: Routledge.

Iyer, K. 1995. Konkan Railway raises hope for development. The Hindu, October 9.

Jasanoff, S. 2011. Cosmopolitan knowledge: climate science and global civic epistemology. In Dryzek, J.S., R.B. Norgaard and D. Schlosberg (eds.) The Oxford handbook of climate change and society. Oxford: Oxford University Press.

Jos, M.K. 1997. Konkan disaster. Times of India, August 22.

Kale, P. 1986. Essentialist and epochalist elements in Goan popular culture: a case study of Tiatr. Economic and Political Weekly 21(47): 2054-2063.

Kale, P. 1994. Goan intellectuals and Goan identity: an unresolved conflict. Economic and Political Weekly 29(16-17): 909-911.

Kamat, N. 2010. Wild panther in Miramar? Goa on the verge of environmental hara-kiri. In Acharya K. and F. Noronha (eds.) The green pen: environmental journalism in India and South Asia. Delhi: Sage Publications India. Pp. 236-248.

Kumar, A. 1996. Patriotism will pay off here. Times of India, November 18. sec. Letter.

Mawdsley, E. 2004. India's middle classes and the environment. Development and Change 35(1): 79-103.

Menezes, G. 1992. Cry, my beloved Goa. Times of India, December 11.

Menezes, M.T. 2000. The essential Goa cookbook. Penguin Books India.

Mhasawade, S. 1998. A backward district begins to move forward. Indian Express, February 22.

Nagarajan, A., G. Radhakrishnan, K.K. Murari and T. Jayaraman. 2015. Appraising the debate on biodiversity conservation in the Western Ghats. Economic and Political Weekly 50(30): 49-56.

Navhind Times. 2003. Goa today, December 5.

Padte, N. 1993. Konkan railways tracing a tortuous path through Goa. Indian Express, December 15.

Panandiker, V.P. and E. Ribeiro. 1993. Divert Konkan Railway to another track. Times of India, May 13.

Paul, S. 1993. Short cut methods? The Telegraph, December 5.

Phadke, R. 2010a. Steel Forests or smoke stacks: the politics of visualisation in the Cape Wind controversy. Environmental Politics 19 (1): 1-20.

Phadke, R. 2010b. Steel forests or smoke stacks: the politics of visualisation in the Cape Wind controversy. Environmental Politics 19 (1): 1-20.

Phadke, R. 2013. Public deliberation and the geographies of wind justice. Science as Culture 22(2): 247255.

Pieterse, J.N. 2000. After post-development. Third World Quarterly 21(2): 175-191.

Plough, A. and S. Krimsky. 1987. The emergence of risk communication studies: social and political context. Science, Technology, and Human Values 12(3/4): 4-10.

Rahman, M. 2013. Goa on my mind. India Today, June 17.

Rodrigues, A. 1993. Opposition to Konkan Railway. Times of India, May 13.

Rubinoff, J.A. 2001. Pink gold: transformation of backwater aquaculture on Goa's Khazan lands. Economic and Political Weekly 36(13): 1108-1114.

Sardesai, R. 1992. Move to realign Goa route. Times of India, May 2. 
Sardesai, R. and A. D'Mello. 1992. The missing link. Times of India, May 3.

Sardessai, M. 2000. A history of Konkani literature: from 1500 to 1992. New Delhi: Sahitya Akademi.

Shanbhag, A.B., R. Walia and S.D. Borges. 2001. The impact of Konkan Railway project on the avifauna of Carambolim Lake in Goa. Zoos' Print Journal 16(6): 503-508.

Shankar, U. 1992a. Goa's food bowl getting bare. Down to Earth, October 31.

Shankar, U. 1992b. Is it on the right track? Down to Earth, October 31.

Sharma, R. 1996. Coasting to growth. Business Standard, September 25.

Short, B. 2006. Idyllic ruralities. In P. Cloke, T. Marsden and P. Mooney (eds.) Handbook of rural studies. Thousand Oaks: Sage. Pp. 133-148.

Sidhva, S. 1996. Engineering marvel nears completion. Financial Times, July 11.

Simoes, F. 1998. Glad seasons in Goa. Viking.

Sinha S., S. Gururani and B. Greenberg. 1997. The 'new traditionalist' discourse of Indian environmentalism. The Journal of Peasant Studies 24(3): 65-99.

Talukdar, S.C. 1962. Economic development of Goa-problems and prospects. Economic and Political Weekly 14(23): 917-920.

The Goa Foundation and Another vs The Konkan Railway Corporation. 1992. Bombay High Court.

Times of India. 1992. Derailing Konkan Railway, April 30, 1992, sec. Editorial.

Vanjari, S. 1968. Goa's village community lands. Economic and Political Weekly 4(14): 843-844.

Varadarajan, R.S. 1992. Young engineers. Times of India, February 27, sec. Letters.

Wagle, N. and G. Coehlo (eds.) 1995. Goa: continuity and change. Toronto: University of Toronto Press.

Western Ghats - UNESCO World Heritage Centre. n.d. Accessed April 30, 2017. http://whc.unesco.org/en/list/1342.

Wetland Inventory. n.d. Ministry of Environment and Forests, Government of India. Accessed April 30.

Woods, M. 2010. Rural: key ideas in geography. London: Routledge.

Worster, D. 1990. Transformations of the earth: toward an agroecological perspective in history. The Journal of American History 76(4): 1087-1106. 